\title{
A novel I 36.2 located gene, APITD I, with tumour-suppressive properties and a putative p53-binding domain, shows low expression in neuroblastoma tumours
}

\author{
C Krona', K Ejeskär',2, H Carén', F Abel', R-M Sjöberg' and T Martinsson*,' \\ 'Department of Clinical Genetics, Institute for the Health of Women and Children, Göteborg University, Sahlgrenska University Hospital-East, SE-4 I 685 \\ Gothenburg, Sweden; ${ }^{2}$ Cell and Gene Therapy Group, University of Melbourne, Murdoch Children's Research Institute, Royal Children's Hospital, Parkville \\ VIC-3052, Australia
}

\begin{abstract}
Neuroblastoma is characterised by a lack of TP53 mutations and no other tumour suppressor gene consistently inactivated has yet been identified in this childhood cancer form. Characterisation of a new gene, denoted APITDI, in the neuroblastoma tumour suppressor candidate region in chromosome Ip36.22 reveals that APITD I contains a predicted TFIID-3I domain, representing the TATA box-binding protein-associated factor, $\mathrm{TAF}_{\|} 3 \mathrm{I}$, which is required for p53-mediated transcription activation. Two different transcripts of this gene were shown to be ubiquitously expressed, one of them with an elevated expression in foetal tissues. Primary neuroblastoma tumours of all different stages showed either very weak or no measurable APITD I expression, contrary to the level of expression observed in neuroblastoma cell lines. A reduced pattern of expression was also observed in a set of various tumour types. APITD / was functionally tested by adding APITD / mRNA to neuroblastoma cells, leading to the cell growth to be reduced up to $90 \%$ compared to control cells, suggesting APITDI to have a role in a cell death pathway. Furthermore, we determined the genomic organisation of APITD I. Automated genomic DNA sequencing of the coding region of the gene as well as the promoter sequence in 44 neuroblastoma tumours did not reveal any loss-of-function mutations, indicating that mutations in APITD/ is not a common abnormality of neuroblastoma tumours. We suggest that low expression of this gene might interfere with the ability for apoptosis through the 553 pathway.

British Journal of Cancer (2004) 91, I | 19- | |30. doi: I0.1038/sj.bjc.6602083 www.bjcancer.com
\end{abstract}

Published online 24 August 2004

(c) 2004 Cancer Research UK

Keywords: I 36; neuroblastoma; TP53; APITD /; TFIID

The chromosomal region 1 p36 is commonly deleted in various paediatric soft tissue tumours including neuroblastoma (Brodeur et al, 1977, 1981), Wilms' tumour (Grundy et al, 1994; Steinberg et al, 2000), embryonal rhabdomyosarcoma (Bridge et al, 2000), pheochromocytoma (Benn et al, 2000) and germ cell tumours (Rodriguez et al, 1992; Stock et al, 1995; Bussey et al, 1999; Mostert et al, 2000; Schneider et al, 2001). Pheochromocytomas and neuroblastomas are both tumours originating in cells derived from the neural crest. We have previously narrowed down the shortest region of overlap of deletions (SRO) in our set of neuroblastoma tumours to $25 \mathrm{cM}$, between the markers D1S244 and D1S80 on chromosome 1, through loss of heterozygosity ( $\mathrm{LOH}$ ) studies of a large number of cases (Martinsson et al, 1995, 1997). A partly overlapping combined neuroblastoma and germ cell tumour SRO of $5 \mathrm{cM}$ was later defined through the inclusion of a teratoma tumour with an interstitial 1p deletion (Ejeskär et al, 2001). Further evidence for the localisation of a neuroblastoma tumour suppressor gene to this region came from the finding of a $500 \mathrm{~kb}$ homozygous deletion within our SRO in a neuroblastoma cell line

\footnotetext{
*Correspondence: Dr T Martinsson;

E-mail: tommy.martinsson@clingen.gu.se

Received 8 December 2003; revised 5 May 2004; accepted 23 June 2004; published online 24 August 2004
}

(Ohira et al, 2000). Mutation analysis of the coding sequences of all known genes within this $500 \mathrm{~kb}$ region indicated a low frequency of amino-acid changes, implying the presence of yet unidentified genes in the region which might be involved in the development and/or progression of neuroblastoma tumours (Ejeskär et al, 2000; Abel et al, 2002; Krona et al, 2003).

In this paper, we have, by means of in silico mapping, identified a gene coding for a domain with similarity to the human TATA box-binding protein-associated factor $\mathrm{TAF}_{\mathrm{II}} 31$ (locus name TAF9). The gene is localised to the $500 \mathrm{~kb}$ hot-spot region in $1 \mathrm{p} 36.2$, between $P G D$ and CORT. TAF $\mathrm{TI}_{\mathrm{II}} 31$ has been identified as a critical protein required for p53-mediated transcriptional activation ( $\mathrm{Lu}$ and Levine, 1995). Based on the localisation of this predicted gene, denoted APITD1 (APoptosis-Inducing, TAF9-like Domain 1), and the fact that TP53 mutations are rare in neuroblastoma tumours (Imamura et al, 1993; Komuro et al, 1993; Vogan et al, 1993; Hosoi et al, 1994), we hypothesised that loss of function for APITD1 could be a way for tumour cells to overcome the cell growthregulating properties of the p53 pathway.

In conclusion, we have characterised a new gene, which might be a member of the proteins involved in cell cycle regulation. Reduced levels of transcription from this gene, APITD1, present as an option for the cell to escape normal regulation during tumorigenesis. 


\section{MATERIALS AND METHODS}

\section{In silico mapping}

In order to identify a putative gene in the neuroblastoma tumour suppressor gene candidate region on chromosome 1p36.22, UCSC Genome Browser August 2001 chromosome 1 draft sequence (URL:http://genome.ucsc.edu) was examined for transcripts, suggested by more than one gene prediction program, within the $500 \mathrm{~kb}$ tumour suppressor gene candidate region. Sequence alignment, open reading frame (ORF) prediction and primer selection were performed using the DNASTAR sequence analysis software (LASERGENE, Madison, WI, USA), or the OLIGO primer analysis software v.6 (Molecular Biology Insights, Cascade, CO, USA). For promoter analysis, genomic sequence from the UCSC contig assembly was analysed using the BDGP Neural Network Promoter Prediction program (URL:http://www.fruitfly.org/seq_tools/promoter.html), and the $\mathrm{CpG}$ island prediction function of the MethPrimer program (URL:http://itsa.ucsf.edu/ urolab/methprimer) (Li and Dahiya, 2002). In order to analyse conservation of the APITD1 gene, the TIGR gene indices (URL:http://www.tigr.org), which contain genomic sequences from a variety of organisms, were searched for expressed sequences translated in all reading frames, with significant similarity to the predicted protein from APITD1.

\section{RNA purification}

Total RNA was extracted from neuroblastoma tumour samples using the Qiagen RNeasy kit for isolation of total RNA from animal tissues (QIAGEN, Valencia, CA, USA). For extraction of total RNA from cell pellets of neuroblastoma cell lines containing approximately $10^{f}$ cells, the Qiagen RNeasy kit for isolation of total RNA from animal cells was used. An additional DNase I digestion procedure (QIAGEN) was included in the isolation of RNA to remove contaminating DNA according to the instructions in the protocol.

\section{Reverse transcription}

cDNA from neuroblastoma tumour samples and cell lines was made using SuperScript ${ }^{\mathrm{TM}}$ II Reverse Transcriptase (Invitrogen, Carlsbad, CA, USA), following the protocol for first-strand synthesis with $1 \mu \mathrm{g}$ of total RNA and $0.5 \mu \mathrm{l}$ of random hexamers (Promega, Madison, WI, USA).

\section{Northern blot}

Total RNA $(10 \mu \mathrm{g})$ from the neuroblastoma cell lines SK-N-AS and SH-SY5Y was subjected to Northern blotting using the North$\operatorname{ernMax}^{\mathrm{TM}}$ Kit (Ambion, Inc., Austin, TX, USA) and nylon membranes (Ambion). Primer sequences for amplification of an APITD1 probe were chosen with the forward primer in exon $2\left(5^{\prime}-\right.$ AAACAGACCATTGCGGCCATT- $3^{\prime}$ ) and the reverse primer in exon $5\left(5^{\prime}\right.$-TTCCAAGCGGCGAGGG-3'); thus, the probe was complementary to both transcript versions of APITD1. Proper normalisation of the relative abundance of total RNA in the panel was assessed using primers for amplification of beta actin $(A C T B)$ : (forward primer) $5^{\prime}$-TCATGAAGTGTGACGTTGACATCCGT-3 and (reverse primer) $5^{\prime}$-CCTAGAAGCATTTGCGGTGCACGATG$3^{\prime}$. The primer pairs were synthesised by Invitrogen. cDNA from SK-N-AS was amplified with these primer pairs with an initial denaturation at $95^{\circ} \mathrm{C}$ for $1 \mathrm{~min}$, followed by amplification for 35 cycles of $30 \mathrm{~s}$ at $95^{\circ} \mathrm{C}, 30 \mathrm{~s}$ at $55^{\circ} \mathrm{C}$ and $2 \mathrm{~min}$ at $72^{\circ} \mathrm{C}$. The PCR products were separated on an agarose gel and amplification products of the appropriate length were cut out from the gel and purified using the QIAquick gel extraction kit (QIAGEN). The hybridisation probes were then labelled with [alpha- $\left.{ }^{32} \mathrm{P}\right]$ cytosine using the Megaprime ${ }^{\mathrm{TM}}$ DNA labelling system (Amersham, Piscataway, NJ, USA). Hybridisation was performed overnight at $42^{\circ} \mathrm{C}$, and the film was exposed for 3-4 days before detection after hybridisation with APITD1 probe and 1 day after hybridisation with the $A C T B$ probe.

\section{Semiquantitative expression analysis}

The tissue-specific expression of the two transcripts of the APITD1 gene was analysed by amplification of commercially available cDNA from CLONTECH's Multiple Tissue cDNA Panels (CLONTECH, Palo Alto, CA, USA) and from OriGene (OriGene Technologies, Inc., Rockville, MD, USA), using two primer pairs. The primer pairs are shown in Figure 1 and listed in Table 1 as APITD1-Expr A-B. Amplification of ACTB was performed as an internal control with the same primer pair that was used for amplification of the ACTB probe for Northern blotting. PCR assays were performed with an initial denaturation at $95^{\circ} \mathrm{C}$ for $1 \mathrm{~min}$, followed by amplification for 30 cycles (ACTB) or 35 cycles (APITD1 transcripts) of $30 \mathrm{~s}$ at $95^{\circ} \mathrm{C}, 30 \mathrm{~s}$ at $54^{\circ} \mathrm{C}$ and $2 \mathrm{~min}$ at $72^{\circ} \mathrm{C}$. All reactions were conducted in a total volume of $50 \mu \mathrm{l}$. The expression of APITD1 was also determined in cDNA reverse transcribed from various primary tumour samples and neuroblastoma cell lines (SK-N-AS, IMR-32, SK-N-F1, SK-N-BE(2) and SH-SY5Y). Additional reactions were performed with control tissues and primer pairs located in varying parts of the predicted transcripts, in order to determine which exons are present in the mature mRNA (Table 1; APITD1-Expr 1-6). We have also analysed the possibility of APITD1 being a part of the adjacent gene CORT. Therefore, two primer pairs were designed, with the forward primer located in APITD1 exon 4 or 5, respectively, and with the reverse primers in the coding sequence of CORT (Table 1; APITD1Expr 7-8). These primer pairs were used in attempts to amplify cDNA by reverse transcriptase-PCR (RT - PCR) at different PCR conditions.

\section{Real-time PCR expression analysis}

Primers and probes for amplification of both APITD1 transcripts were designed spanning intron 1 . They were ordered through the Applied Biosystems 'TaqMan ${ }^{\circledR}$ Assays-by-Design ${ }^{\text {SM }}$ Gene Expression Service' facility (URL:http://myscience.appliedbiosystems.com). TaqMan primers and probe for GUSB ( $\beta$-glucuronidase) were derived from Applied Biosystems 'TaqMan ${ }^{\mathbb{B}}$ Assays-onDemand $^{\mathrm{TM}}$ Gene Expression Products' and amplification of GUSB was used as an internal control for the integrity and relative amount of mRNA. The real-time PCR reactions were performed using an ABI PRISM ${ }^{\circledR}$ 7900HT Sequence Detection System (Applied Biosystems, Foster City, CA, USA). The mean $C_{\mathrm{T}}$ values for duplicate samples of neuroblastoma cell lines or neuroblastoma tumours were used to calculate the amount of both transcripts from a standard curve. The calculated expression levels were then normalised to the amount of GUSB in each sample in order to achieve a relative expression amount. This relative expression amount of both transcripts in a group of four stage 2 tumours from children with no residual evidence of disease was compared with a two-sample $t$-test to a group of six stage 3 or stage 4 tumours from children who had died of the disease.

\section{Hybrid panel mapping}

In order to assure the chromosomal localisation of the APITD1 gene, we used the NIGMS human/rodent somatic cell hybrid mapping panel \#2, version 3 (Coriell Institute, Camden, NJ, USA). The primer pair for amplification of exon 4 (Table 1; APITD1-Exon 4) was used in amplification reactions, with $100 \mathrm{ng}$ DNA from hybrid cells representing all human chromosomes, for 30 cycles ( $30 \mathrm{~s}$ at $95^{\circ} \mathrm{C}, 30 \mathrm{~s}$ at $55^{\circ} \mathrm{C}$ and $1 \mathrm{~min}$ at $72^{\circ} \mathrm{C}$ ). PCR products were 
A

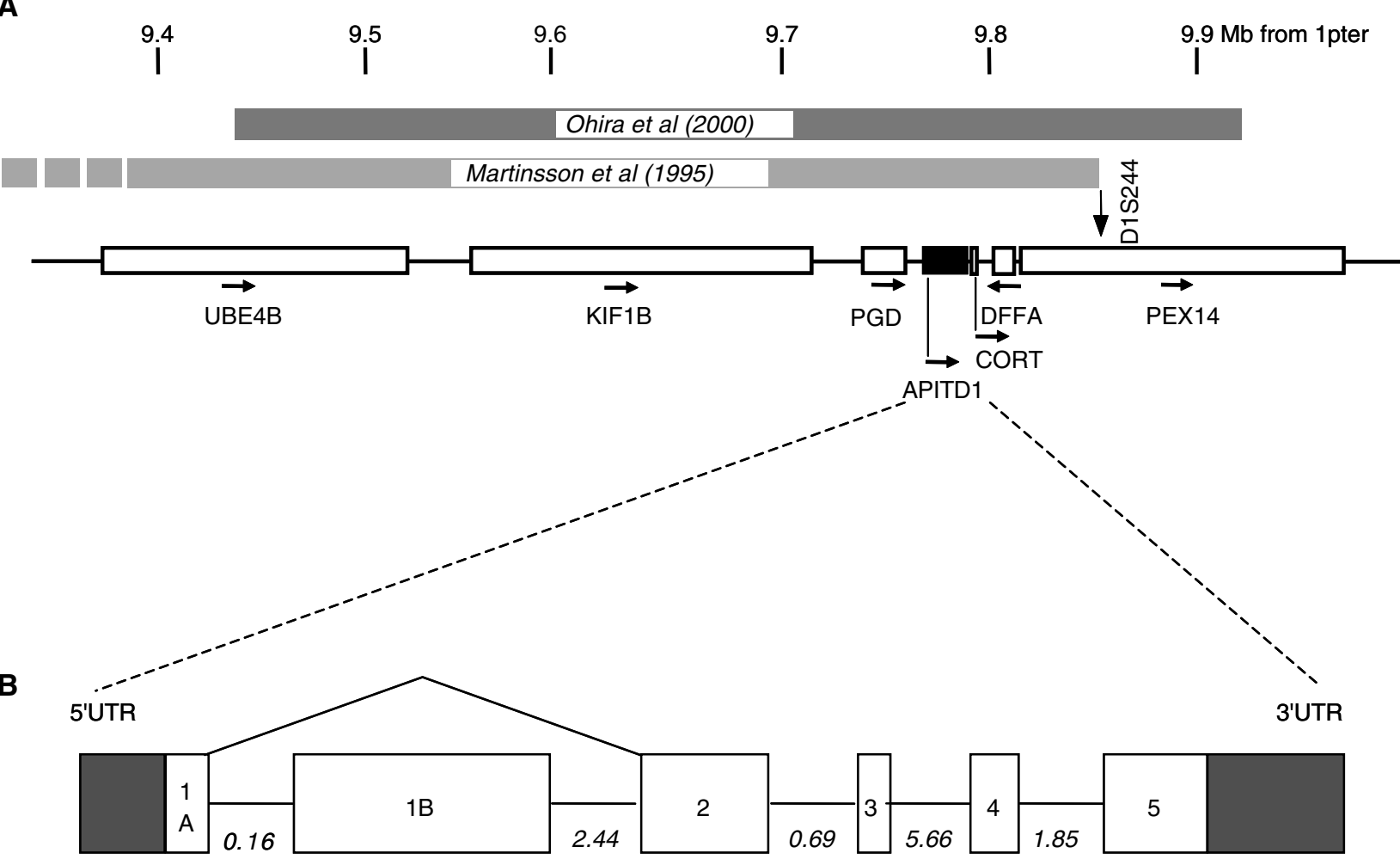

Length of CDNA

PCR product

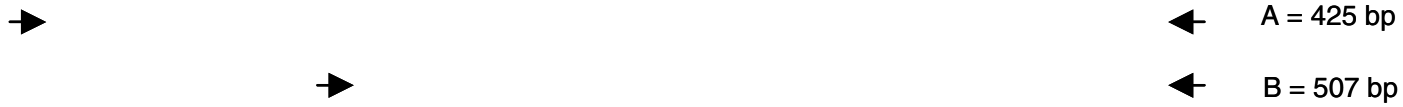

Figure I (A) Map of the Ip36.2 neuroblastoma tumour suppressor gene candidate region. The location of the genes is based on data from the UCSC genome browser; April 2002 draft sequence. The homozygously deleted region on chromosome Ip in a neuroblastoma cell line, found by Ohira et al (2000), is indicated by a dark shaded box, while the neuroblastoma SRO as defined by our group (Martinsson et al, 1995) is shown as a light grey box. The region includes the genes UBE4B, KIFIB, PGD, APITDI, CORT, DFFA and PEXI 4. ICAT is located just distal of the region. APITD I is marked with a black box. Arrows indicate the transcriptional direction of the genes. The scale in the top is the approximate distance from the I p-terminal, in mega base pairs. (B) The genomic organisation of the APITD / gene, with the two alternative first exons, is shown with intron sizes indicated in kb. The location of the primers used for amplification of transcripts $A$ and $B$ from cDNA for RT-PCR expression analysis is also illustrated.

then loaded onto a $2 \%$ agarose gel, stained with ethidium bromide and visualised under UV illumination.

\section{In vitro transcription of mRNA}

DNA fragments of the coding region of transcript A from APITD1 linked to the Sp6 promoter sequence and a polyA tail at the end of the fragment were constructed by PCR using primers: (forward primer) 5 -ATTTAGGTGACACTATAGAAGATTGCCCAGGGTC GGCCCGCAGTGATG-3' and (reverse primer) $5^{\prime}-\mathrm{GG}(\mathrm{T})_{30}$ ACAATGTGGAGAATTCAGCAC-3', with IMAGE clone 4051739 (gene bank locus: BC029430) as a template. The PCR was performed using High Fidelity Taq (Roche Diagnostics, Mannheim, Germany) according to the supplier's protocol, with an annealing temperature of $60^{\circ} \mathrm{C}$ and 30 cycles of PCR. In all, $500 \mathrm{ng}$ of the PCR product ( $663 \mathrm{bp}$ ) was used as a template for in vitro mRNA using mMESSAGE mMachine (Ambion). The procedure was according to the supplier's protocol using $4 \mathrm{~h}$ incubation at $37^{\circ} \mathrm{C}$. The mRNA was DNase I treated for $15 \mathrm{~min}$ at $37^{\circ} \mathrm{C}$ and $\mathrm{LiCl}-$ precipitated before size and concentration evaluation by agarose gel electrophoresis. The control green fluorescent protein (GFP) mRNA was produced using $500 \mathrm{ng}$ of EcoRI-digested Sp6-EGFP vector as template in the in vitro mRNA reaction. The concentrations of GFP mRNA and APITD1A mRNA were adjusted to be equal and evaluated on agarose before each further experiment.

\section{Cell culture}

The neuroblastoma cell lines SK-N-BE(2) and SK-N-AS (American Type Culture Collection (ATCC), Manassas, VA, USA), the embryonic kidney derived cell line 293 (ATCC) and the lymphoblast cell line K562 (ATCC) were cultured in Dulbecco's modified Eagle medium (Invitrogen) with $10 \%$ foetal calf serum (Sigma-Aldrich Corp., St Louis, MO, USA) in $37^{\circ} \mathrm{C}$ using standard procedures. Cells with $60-80 \%$ confluence were used in transfection experiments. Immediately before the transfection procedure, the SK-N-BE(2) cells, the SK-N-AS cells and the 293 cells were trypsinised and washed twice with PBS, and the cell numbers and the viability were calculated using trypan blue staining. The 
Table I PCR primers used in this study

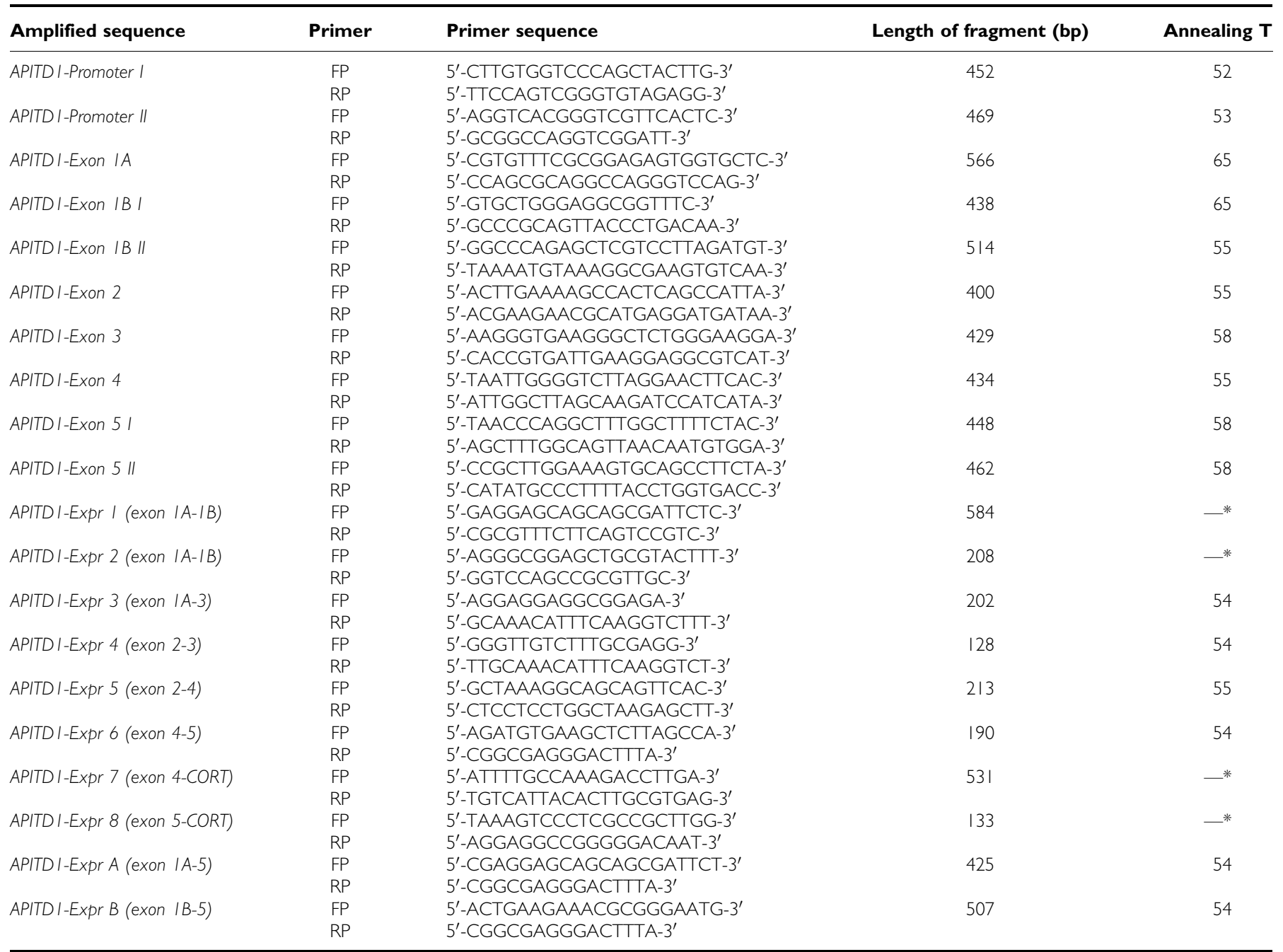

Column I: amplified sequence; Promoter I and Promoter II are overlapping primer pairs, which together cover 800 bp before the initiation codon in transcript A; Exon I B I and Exon I B I/ cover the starting exon (IB) in transcript B together; Exon 5 I and Exon 5 || cover exon 5 and approximately 500 bp into the 3' UTR region; APITD I-Expr primers are located in the exons indicated within the parantheses, and they were used for amplification of CDNA. Column 5: Annealing temperature for PCR amplification; *No PCR product was obtained with the APITD I-Expr I, -Expr 2, -Expr 7 and -Expr 8 primers at various temperatures, implying that exons IA and IB are not in the same transcript, and that APITD I is not in the same transcription unit as the nearby located gene CORT.

suspension cells K562 were used only if the viability was $90 \%$ or more at the day of transfection.

\section{Transfection}

The transfection experiments were performed in a 12-well plate using $4 \times 10^{5}$ cells well $^{-1}$ for SK-N-BE(2), SK-N-AS, and K562 cells and $7 \times 10^{5}$ cells well $^{-1}$ for 293 cells, all in $2 \mathrm{ml}$ Dulbecco's modified Eagle medium with $10 \%$ foetal calf serum per well. For each transfection, a total of $1.5 \mu \mathrm{g}$ of mRNA (A: $1.5 \mu \mathrm{g}$ GFP mRNA; B: $0.3 \mu \mathrm{g}$ APITD1A mRNA + $1.2 \mu \mathrm{g}$ GFP mRNA; C: $1.5 \mu \mathrm{g}$ APITD1A mRNA) and $5 \mu$ l Lipofectamine-2000 (Invitrogen) were used. The mRNA and the Lipofectamine-2000 were incubated for $30 \mathrm{~min}$ in $200 \mu \mathrm{l}$ serum-free medium (Opti-MEM, Invitrogen) before being added to the cell suspensions. The cell and Lipofectamine2000-mRNA complex mix was immediately divided into 96-well plates at $10^{4}$ cells well $^{-1}$ (SK-N-BE(2), SK-N-AS, K562) or $1.7 \times 10^{4}$ cells well $^{-1}(293)\left(50 \mu \mathrm{lwell}^{-1}\right)$, and incubated at $37^{\circ} \mathrm{C}$ for $5 \mathrm{~h}$ before an extra $50 \mu \mathrm{l}_{\text {well }}^{-1}$ of Dulbecco's modified (Eagle) medium with $10 \%$ foetal calf serum was added. The cells were incubated for $1-4$ days at $37^{\circ} \mathrm{C}$ for cell growth studies.

\section{Cell growth studies}

After incubation for $1,2,3$ and 4 days, respectively, at $37^{\circ} \mathrm{C}, 20 \mu \mathrm{l}$ of CellTiter96 AQueous One Solution Cell Proliferation Assay (Promega) was added to each 96-well plate with $100 \mu$ l cell suspension. For each experiment, four separate wells were tested at each time point. The mix was incubated in the dark at $37^{\circ} \mathrm{C}$ for $4 \mathrm{~h}$ before the absorbance at $490 \mathrm{~nm}$ was evaluated in an ELISA reader. The cell number in each well was calculated using a standard curve with known cell numbers using the same procedures as above. The mean number of cells per well was calculated for each experiment at each time point. At 1 day after transfection, the transfection efficiency was evaluated using fluorescence microscopy, by counting the number of green cells in the GFP mRNA experiments. Experiments comparing different mRNA:s were performed from the same batch of cells and treated equally all through the experimental procedure. 


\begin{tabular}{|c|c|c|c|c|c|c|c|c|c|}
\hline DNA variation & $\begin{array}{l}\text { Genomic } \\
\text { location }\end{array}$ & \multicolumn{4}{|c|}{ Tumours } & \multicolumn{4}{|c|}{ Controls } \\
\hline c. I-464 T>C & Promoter $^{\mathrm{a}}$ & 44 & 30 (68\%) & $6(14 \%)$ & $8(18 \%)$ & 38 & $18(47 \%)$ & $8(21 \%)$ & $12(32 \%)$ \\
\hline c. $1-290 \mathrm{~T}>\mathrm{C}$ & Promoter $^{\mathrm{a}}$ & 44 & $29(66 \%)$ & $6(14 \%)$ & $9(20 \%)$ & 42 & 14 (33\%) & $14(33 \%)$ & $14(33 \%)$ \\
\hline c. $1-225 G>A$ & Promoter ${ }^{a}$ & 44 & I (2\%) & 0 & $43(98 \%)$ & 42 & 0 & 0 & $42(100 \%)$ \\
\hline c. $1-25 G>C^{b}$ & $5^{\prime} \cup T^{c}$ & 44 & $10(23 \%)$ & 0 & $34(77 \%)$ & 38 & 7 (I8\%) & $2(5 \%)$ & $29(76 \%)$ \\
\hline c. I-644 A > G & $5^{\prime} \cup T R^{d}$ & 44 & $29(66 \%)$ & $8(\mid 8 \%)$ & $7(16 \%)$ & 48 & $12(25 \%)$ & $21(44 \%)$ & $15(31 \%)$ \\
\hline c. $1-316$ A > G & $5^{\prime} \cup T R^{d}$ & 44 & $10(23 \%)$ & $34(77 \%)$ & 0 & 46 & $2(4 \%)$ & $42(91 \%)$ & $2(4 \%)$ \\
\hline c.277-(14-5) ins T & Intron $4^{b}$ & 44 & $6(14 \%)$ & 0 & 38 (86\%) & 43 & $10(23 \%)$ & 0 & $33(77 \%)$ \\
\hline$c .665 A>G$ & $3^{\prime} \cup T R^{c}$ & 44 & $10(23 \%)$ & $33(75 \%)$ & I (2\%) & 46 & $7(15 \%)$ & 37 (80\%) & $2(4 \%)$ \\
\hline
\end{tabular}

The UCSC Genome Browser August 200 I Chromosome I draft sequence was used as a reference sequence, with the A in the initiation codon starting at base I 35 in transcript A (chrl_29_927.b) denoted nucleotide I. 'binkage disequilibrium is present between the two variations. ${ }^{~}$ Transcript A was used as a reference. ${ }^{\mathrm{d}}$ Transcript B (chrl_29_927.g) was used as a reference. Base number I was assigned to the A base of an initiation codon starting at base 736 in the transcript. Column 3: number of tumour samples screened for each variation. Columns 4-6: number of tumour samples with each observed allele and frequency of the allele in the screened population; HetZ, heterozygote; HomZ, homozygote; HemZ, hemizygote; ref., reference; seq., sequence. Column 7: number of control samples screened for each variation. Columns $8-10$ : number of control samples with each observed allele and frequency of the allele in the screened population; HetZ, heterozygote; HomZ, homozygote; ref., reference; seq., sequence.

\section{DNA sequencing}

Genomic DNA extracted by standard procedures from 44 frozen $\left(-70^{\circ} \mathrm{C}\right)$ primary neuroblastoma tumours of all different stages was used for sequencing analysis. The tumours were staged according to the International Neuroblastoma Staging System criteria (Brodeur et al, 1988, 1993). Four were stage 4S, four were stage 1 , three were stage $2 \mathrm{a}$, one was stage $2 \mathrm{~b}, 13$ were stage 3,15 were stage 4 and four were of unknown stages. Of the stage 3 and 4 tumours, 16 had $1 \mathrm{p}$ deletion, as determined by FISH and/or microsatellite analysis. DNA was also extracted from EDTA blood, obtained from control individuals. The sequence results from the tumour samples were compared to the reference sequences from the UCSC Genome Browser (chr1_29_927.b and chr1_29_927.g). Control samples were also included in the sequencing of all exons, according to Table 2. Primers for amplification of the coding sequences of the gene as well as the predicted promoter sequences are listed in Table 1. The concentration of PCR products was estimated by comparison to a low DNA mass ladder (Invitrogen) on an agarose gel. The PCR products were purified with ExoSAPIT (USB, Corp., Cleveland, OH, USA). The sequencing reactions were made using ABI PRISM Big Dye Terminator Cycle Sequencing Ready Reaction Kit (Applied Biosystems) according to protocols. Sequencing was performed using an ABI PRISM 3100 DNA Sequencer (Applied Biosystems). Sequence analysis was conducted using the Vector NTI sequence analysis software (InforMax, Frederick, MD, USA). In cases where a deviation from the reference sequence was observed, it was confirmed through resequencing from the opposite direction.

\section{RESULTS}

\section{Genomic organisation of APITD1}

A gene was predicted to reside distal to the CORT gene but proximal to the $P G D$ gene, in the neuroblastoma tumour suppressor gene candidate region on chromosome 1p36.22. Due to similarity to the TFIID-31 domain in the transcription initiation factor $\mathrm{TAF}_{\mathrm{II}} 31$ (locus name TAF9), it was denoted APITD1 (APoptosis-Inducing, TAF9-like Domain 1). Two alternative versions of the gene were proposed from the predicted mRNA sequences at the UCSC Genome Browser. A closer examination of a 1214 bp long predicted mRNA, chr1_29_927.b (APITD1 transcript
A) showed that the sequence between bases 588 and 1111 is identical to exon 2 of the nearby located gene CORT and the last 103 bases in the predicted transcript between bases 1112 and 1214 is probably not a transcribed genomic sequence. Using RT-PCR, we demonstrated that exon 2 of CORT is not included in the APITD1 transcript A; thus a $587 \mathrm{bp}$ long transcript remains (Figure 2). A 1331 bp long transcript, chr1_29_927.g, with an alternative first exon was also predicted (APITD1 transcript B) (Figure 2). Sequence alignment of these transcripts against genomic sequences from the public databases determined the genomic structure of APITD1 to consist of six exons spread over approximately $13 \mathrm{~kb}$ (Figure 1). Two CpG islands with a GC content of more than $80 \%$ were identified preceding and overlapping the first exons of both transcript versions of the gene. A possible transcription promoter was predicted to reside approximately $200 \mathrm{bp}$ prior to exon $1 \mathrm{~A}$. The longest ORF in transcript A stretches from base 135 to 548 and it encodes a hypothetical protein of 138 amino acids with a molecular weight of $16 \mathrm{kDa}$ (Figure 2). The translation start site in this transcript is set within the correct context for translation initiation with a purine at -3 and $G$ at +4 (Kozak, 1996). In transcript B, however, there is no ORF with the optimal translation initiation context. Two ORFs of adequate length exist in the transcript, both with a $\mathrm{C}$ at position +4 instead of the consensus nucleotide G. The first ORF is set between base 266 (in exon 1B) and 631. No related human sequences are retrieved through BLAST searches of nucleotide and protein databases, with the hypothetical protein translated from this ORF. The other ORF runs in the same reading frame as the ORF in transcript A; it is located between base 736 (in exon 2) and 1032 and it encodes for a hypothetical protein of 99 amino acids with a molecular weight of $11 \mathrm{kDa}$ (Figure 2). This ORF, like the ORF in transcript $A$, encodes an amino-acid sequence with homology to the TFIID-31 subunit of the transcription initiation factor TFIID, required for p53-mediated transcription activation. The translated ORF in transcript A also displays a high sequence similarity to translated expressed sequences from other organisms than human (Figure 3).

\section{Northern blot}

Northern blot hybridisation of neuroblastoma cell lines SK-N-AS and SH-SY5Y with use of a radio labelled APITD1 probe identified two transcripts of approximately 1.5 and less than $1 \mathrm{~kb}$ 
1 GAGGCAGGGCGGAGCTGCGTACTTTGTCCGCCCGCGCGGCCCGTCGCTCGCGCCGC

57

147

$\begin{array}{llllllllllllllllll}A & E & T & E & E & Q & Q & R & F & S & Y & Q & Q\end{array}$

Exon $1 B$

1 GCGGTTTCCGCGGCAACGCGGCTGGACCCTGGCCTGCGCTGGCTGGGGAGGAAGCGGTTCTAGGGGAGCGTGCGGGCGCCGGGGTCCGGC

91 GACGAGAGGCCACCTTCTGGCCTTGCGATGAATCCTCGGTTTCCCCTTCTCAGATGGGGTTTTCGTGAGGGTACAACGTCGGCATTAGAC

181 ATTCCAGGTGACGCCCGTACGCGGTGGGCGGTTCGGGCCGGAGCTCTGGAACGCTGGCCCTGGAGGCGTCGACCCCTCGTTACTGATGCA

271 GGGACGCGGTGCGGACCAGTCAGGCCCAGAGCTCGTCCTTAGATGTGGGTTCGAATCTCTGCCCCGCCAACTTGTGATCGTATCGACTCG

361 GCCCAGACGCAATTTTCTTCTCTGCAAAATCGTCATAAGAATAATCACTTGTCAGGGTAACTGCGGGCATCCCATTCGTTCCTTTCATCA

451 GCGCCGGGCATATGGGGCGTCAGAGGCTGAGAACGTTGCCGTGAAGAGGCTTAAAAGCAAGACCCGGAGTGGCGACCTTAAAGAGGACGG

541 ACTGAAGAAACGCGGGAATGAGCTCCAGACGCGGGAGTTTCCTCTCTACAAAGTTACACTGCAGCAGCTGTCTACCCTGCCCCTTGTCTT

631 TTGAGAAGTTCAAACCTTCAGAAAAGTTGCAAGAACACG...

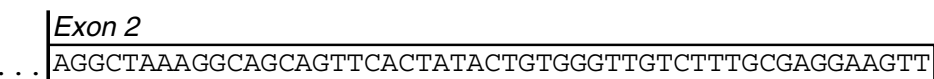

$$
\begin{aligned}
& \text { … AGGCTAAA GGCAGCAGTTCACTATACTGTGGGTTGTCTTTGCGAGGAAGTT }
\end{aligned}
$$

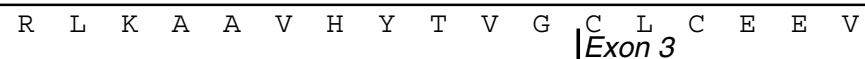

237 GCATTGGACAAAGAGATGCAGTTCAGCAAACAGACCATTGCGGCCATTTCGGAGCTGACTTTCCGACAGTGTGAAAATTTTGCCAAAGAC 721 GCATTGGACAAAGAGATGCAGTTCAGCAAACAGACCATTGCGGCCATTTCGGAGCTGACTTTCCGACAGTGTGAAAATTTTGCCAAAGAC

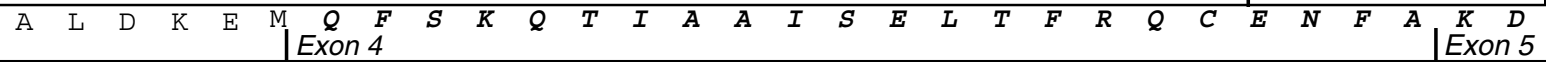

327 CTTGAAATGTTTGCAAGACATGCGAAAAGAACCACAATTAACACTGAAGATGTGAAGCTCTTAGCCAGGAGGAGTAATTCACTGCTAAAA 811 CTTGAAATGTTTGCAAGACATGCGAAAAGAACCACAATTAACACTGAAGATGTGAAGCTCTTAGCCAGGAGGAGTAATTCACTGCTAAAA $\begin{array}{lllllllllllllllllllllllllllllllll}L & E & M & F & A & R & H & A & K & R & T & T & I & N & T & E & D & V & K & L & L & A & R & R & S & N & S & L & L & K\end{array}$

417 TACATCACAGACAAAAGTGAAGAGATTGCTCAGATTAACCTAGAACGAAAAGCACAGAAGAAAAAGAAGTCAGAGGATGGAAGCAAAAAT 901 TACATCACAGACAAAAGTGAAGAGATTGCTCAGATTAACCTAGAACGAAAAGCACAGAAGAAAAAGAAGTCAGAGGATGGAAGCAAAAAT $\begin{array}{llllllllllllllllllllllllllllllllll}\boldsymbol{Y} & \boldsymbol{I} & \boldsymbol{T} & \boldsymbol{D} & \boldsymbol{K} & \boldsymbol{S} & \boldsymbol{E} & \boldsymbol{E} & \boldsymbol{I} & \boldsymbol{A} & \boldsymbol{Q} & \boldsymbol{I} & \boldsymbol{N} & \boldsymbol{L} & \boldsymbol{E} & \boldsymbol{R} & \boldsymbol{K} & \boldsymbol{A} & \boldsymbol{Q} & \mathrm{K} & \mathrm{K} & \mathrm{K} & \mathrm{K} & \mathrm{S} & \mathrm{E} & \mathrm{D} & \mathrm{G} & \mathrm{S} & \mathrm{K} & \mathrm{N}\end{array}$

507 TCAAGGCAGCCAGCAGAGGCTGGAGTGGTGGAAAGTGAGAATTAAAGTCCCTCGCCGCTTGGAAAGTGCAGCCTTCTACAG 991 TCAAGGCAGCCAGCAGAGGCTGGAGTGGTGGAAAGTGAGAATTAAAGTCCCTCGCCGCTTGGAAAGTGCAGCCTTCTACAGGTAGAGCCA $\begin{array}{lllllllllllllll}S & R & Q & P & A & E & A & G & V & V & E & S & E & N\end{array}$

\section{CCTAGAAATGCATATGGCTGCAAAGGAAACTTTGAAGGGTTAAATAGAGATTTAAAAAAATAAAATAAAAAGGCTGGGCTAGGGTGCTTT}

1171 TTGTGCTGAATTCTCCACATTGTTAACTGCCAAAGCTAGTTTTAGAGAATGAGAAAGTCTTAAGCAAAATACTCCCAGGTCTCACTCCAG

1261 AACATAAAAATGGTGTGTGATCAAATGGTATATATTAGAAATTACATCTGTTGTAATTAAAATTGTGTGAg

Figure 2 The two alternative transcript versions of the APITD / gene. Both transcripts share exons 2-5, but they differ in the starting exons and in the 3'UTR sequences. Exon IA is located approximately $160 \mathrm{bp}$ upstream of exon IB in the genomic sequence. The translated sequence from the ORF in transcript $A$ and the in-frame ORF in transcript $B$, which starts immediately prior to the putative TFIID-3I domain, is shown. The amino-acid sequence with significant similarity to the TFIID-3I domain is marked in bold face and italics. The last 622 bp of transcript A (chrl_29_927.b), which consists of exon 2 from the nearby located gene CORT and noncoding genomic sequence, is not shown.

respectively. The higher molecular weight transcript was more abundant (Figure 4).

\section{Transcript variants from the APITD1 gene}

In order to establish which exonic sequences are transcribed from the APITD1 gene, RT-PCR was performed on cDNA extracted from kidney, foetal kidney, brain, foetal brain and stomach, using primer pairs located in various exons (Table 1). Attempts to amplify the sequence between exons $1 \mathrm{~A}$ and $1 \mathrm{~B}$ failed, implying that these exons are located in different transcripts. All other combinations of amplification that are listed in Table 1 resulted in PCR products of the expected sizes (data not shown). There was no amplification product in the RT-PCR reactions when forward 


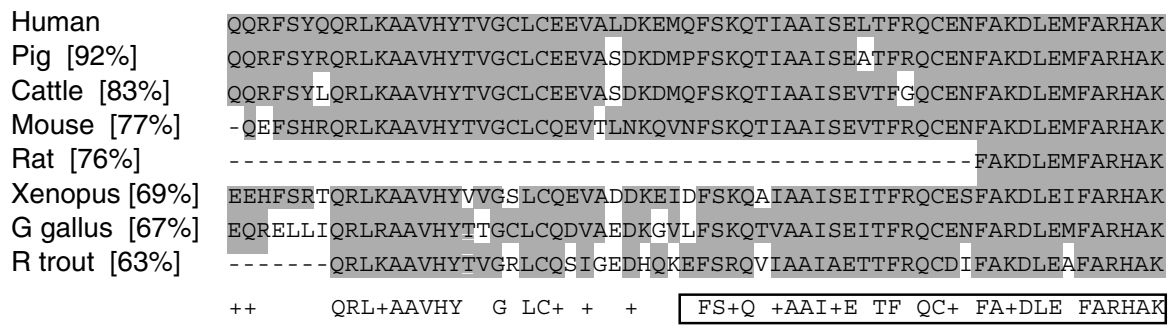

\begin{tabular}{|c|c|}
\hline Human & RTTINTEDVKLLARRSNSLLKYITDKSEEIAQINLERKAQKKKKSEDGSKNSRQPAEAGVVESE \\
\hline Pig & RSTINTEDVKLLARRSNSL- - - - - - \\
\hline Cattle & RSTINTEDVKLLARRSHSLLKYITEKNEDIAQLNLEKKAKKKKKLEDENRNSVESAEAGVEESE \\
\hline Mouse & RSTVTTEDVKLLARRNNSLLKYITEKNEE IAQLNLKGKAKKKRKPEDESRSSRE- - - - - \\
\hline Rat & RSTITTDDVKLLLRRSNSLLKYITEKNKEIAQLNLEQKAKKKRKSED- - - - \\
\hline Xenopus & RTTINMDDVKLLARRSRSLYAHISKCSDEIAANSLEQKEKKKKKSVSGGNVSR - - - - - - - - \\
\hline G gallus & RSTITSEDVKLLARRSNSLLKYITQKSDELASSNMEQKEKKKKKSSAAKGRKTEENETPVTESE \\
\hline R trout & RSTVSVEDVKLTARRSTALANFIQRKSEEIASANQEQRDTRKK- - - - - - - - - - - - - \\
\hline
\end{tabular}

Figure 3 Conserved amino acids in the translated APITD / transcript A ORF. The first nine amino acids in the translated ORF did not align to the translated expressed sequences from other organisms in the TIGR database, and they are not shown. Percent identity with the human sequence is shown within brackets after the name of each organism. Residues which are identical or chemically similar to the human amino-acid sequence are highlighted in grey. The residues which are identical or similar among all aligned sequences are indicated under the alignment, and the TFIID-3I similar domain is framed.
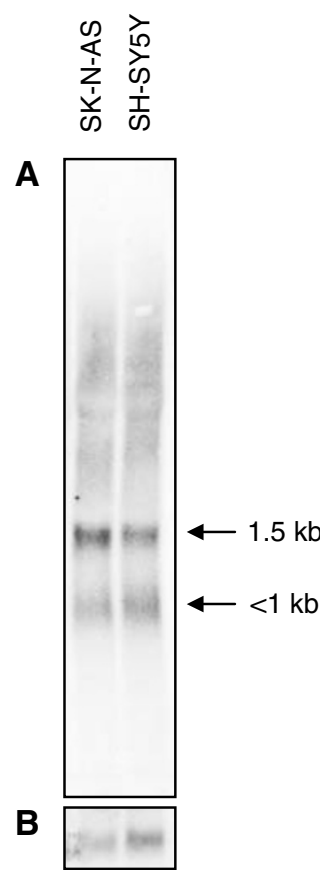

Figure 4 Transcript size of the APITD/ gene. Northern blot analysis of total RNA isolated from the neuroblastoma cell lines SK-N-AS and SHSY5Y. The blot was hybridised with a radio labelled probe. (A) APITD I. (B) ACTB internal loading control.

primers, located in APITD1, were used with reverse primers located in CORT. Thus, our data show that APITD1 is a gene distinct from CORT.

\section{Tissue-specific expression}

Both APITD1 transcripts were ubiquitously expressed in all tested normal tissues, with an especially high level of expression in the adult testis of both transcripts and in the adult kidney of transcript B. A low level of expression of transcript B was detected in the peripheral blood leukocyte and spleen from adult tissues, and in the skeletal muscle and thymus from foetal tissues (Figure 5A). The expression of transcript A was generally higher in foetal tissues than in adult tissues, while the opposite situation occurred for transcript B.

\section{APITD1 expression in tumour samples and neuroblastoma cell lines}

The APITD1 transcripts were either not expressed or only present at low levels in both neuroblastoma tumours (Figure 5B) and a set of various tumour types (Figure 5C). A PCR product of length shorter than $507 \mathrm{bp}$ was also observed in the amplification reaction of transcript B in some tumours. This product was analysed by sequencing, and was shown to be an amplification product originating from a gene on chromosome 16, with a partial sequence homology to the primer sequences (data not shown). The expression of both transcripts was markedly reduced compared to the level of expression in normal tissues and in the neuroblastoma cell lines, with the exception of IMR-32, which had a weak expression of both transcripts.

A more sensitive screening by quantitative real-time PCR revealed that the mean relative expression level of transcript A was significantly lower in the high-stage tumours (mean 0.07; s.d. 0.03 ) than in the low-stage tumours (mean 0.35 ; s.d. 0.17 ) $(P=0.0022)$. There was also a significant difference $(P=0.0016)$ in the relative mean expression levels of transcript $B$ between the high-stage tumours (mean 0.74 ; s.d. 0.26 ) and the low-stage tumours (mean 1.85; s.d. 0.43). The relative amount of the APITD1 transcripts was considerably higher in the cell lines than in the tumour samples (Table 3).

\section{Hybrid panel mapping}

PCR products of the expected size ( $434 \mathrm{bp}$ ) were obtained in the chromosome 1 cell hybrid and in the human cell line control exclusively (Figure 6). 
A
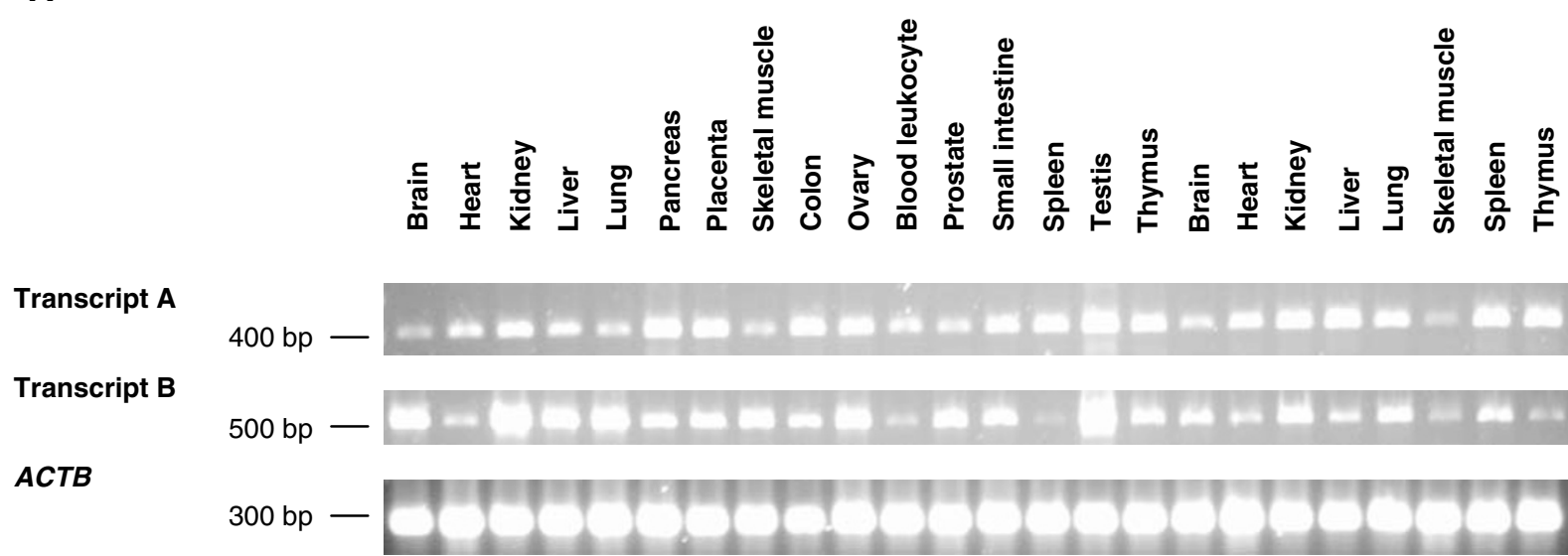

B
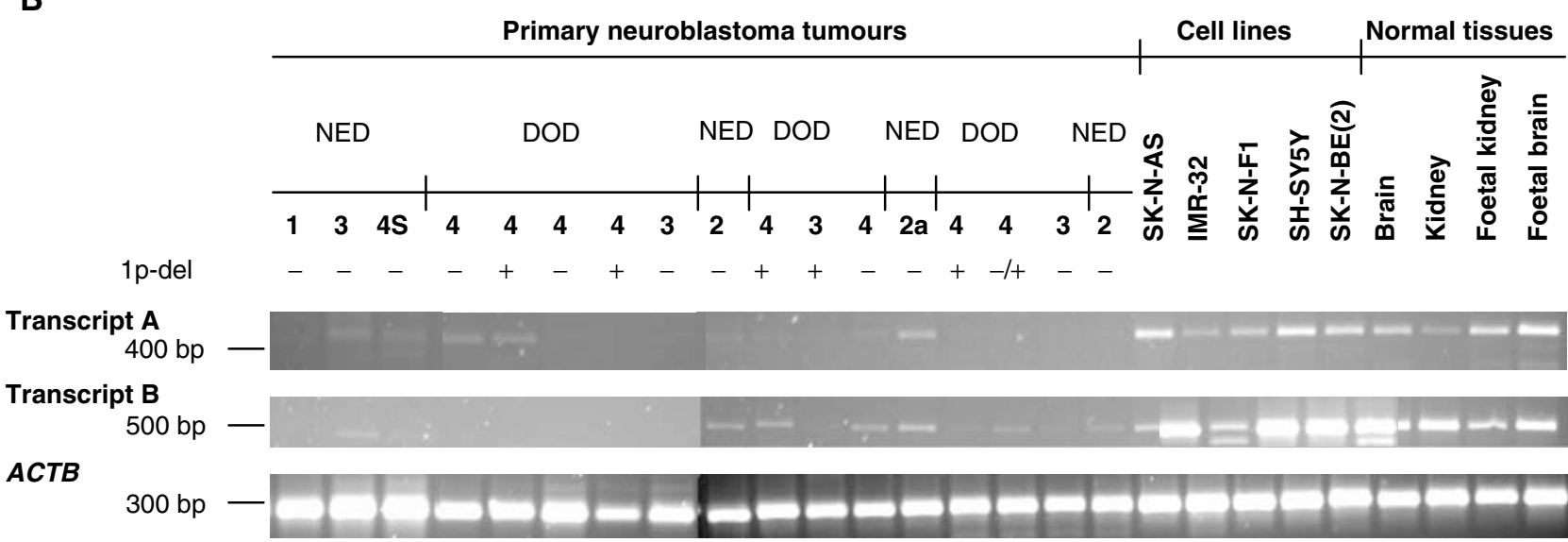

C

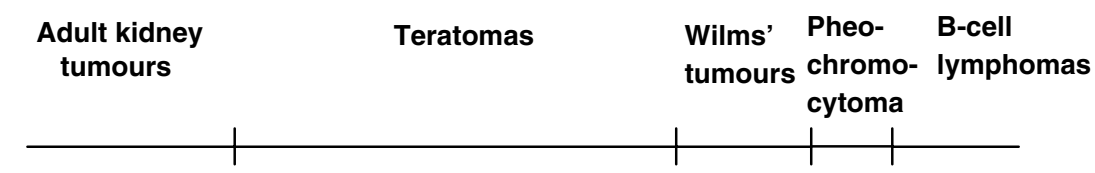

Transcript A

$$
400 \mathrm{bp}-
$$

Transcript B

ACTB

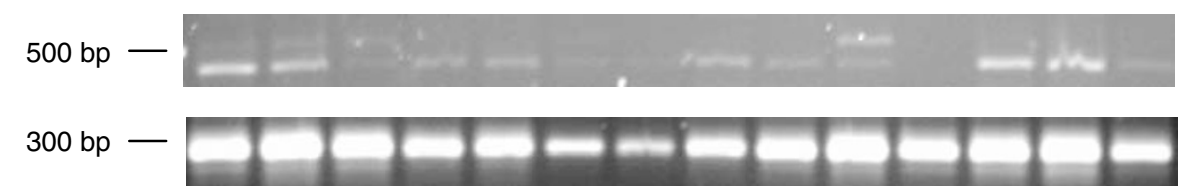

Figure 5 RT-PCR expression analysis of transcripts $A$ and $B$ in APITD I. Amplification of APITD / transcript $A$ and APITD / transcript B in each sample is compared to the amplification of ACTB. (A) Fairly ubiquitous expression of both transcripts in a set of normal adult and foetal tissues (CLONTECH). Lanes I-24, PCR products from the indicated tissues. (B) Reduced expression of APITD / gene products in neuroblastoma tumours of different stages compared to neuroblastoma cell lines and adult and foetal normal tissues (OriGene). The outcome of the patients, the stage of neuroblastoma and the status of chromosome I $p$ is indicated above the upper panel; NED, no evidence of disease; DOD, dead of disease; I, 2, 2a, 3, 4 and 4S, stages of neuroblastoma; -, negative for I p deletion; +, positive for I p deletion; \pm , uncertain result (based on FISH and microsatellite analysis). Lanes I- I7, neuroblastoma tumours; lanes I8-26, neuroblastoma cell lines and normal tissues as indicted above the panel. (C) Reduced expression of APITD I gene products in various tumours. Lanes $1-14$, tumours of various types as indicated above the panel.

\section{Functional studies on cell growth}

The mRNA transfection experiments showed that by adding $1.5 \mu \mathrm{g}$ of APITD1A mRNA to the neuroblastoma cell line SK-N-AS the cell number was reduced by $70 \%$ after $24 \mathrm{~h}$, and by $90 \%$ after $2-4$ days of incubation, compared to GFP mRNA-transfected cells. If $0.3 \mu \mathrm{g}$ APITD1A mRNA was mixed with $1.2 \mu \mathrm{g}$ of GFP mRNA, the reductions in cell numbers after $24 \mathrm{~h}$ were $40 \%$ and $65 \%$ after $2-4$ 
Table 3 Amounts of APITD / transcripts measured by quantitative real-time PCR

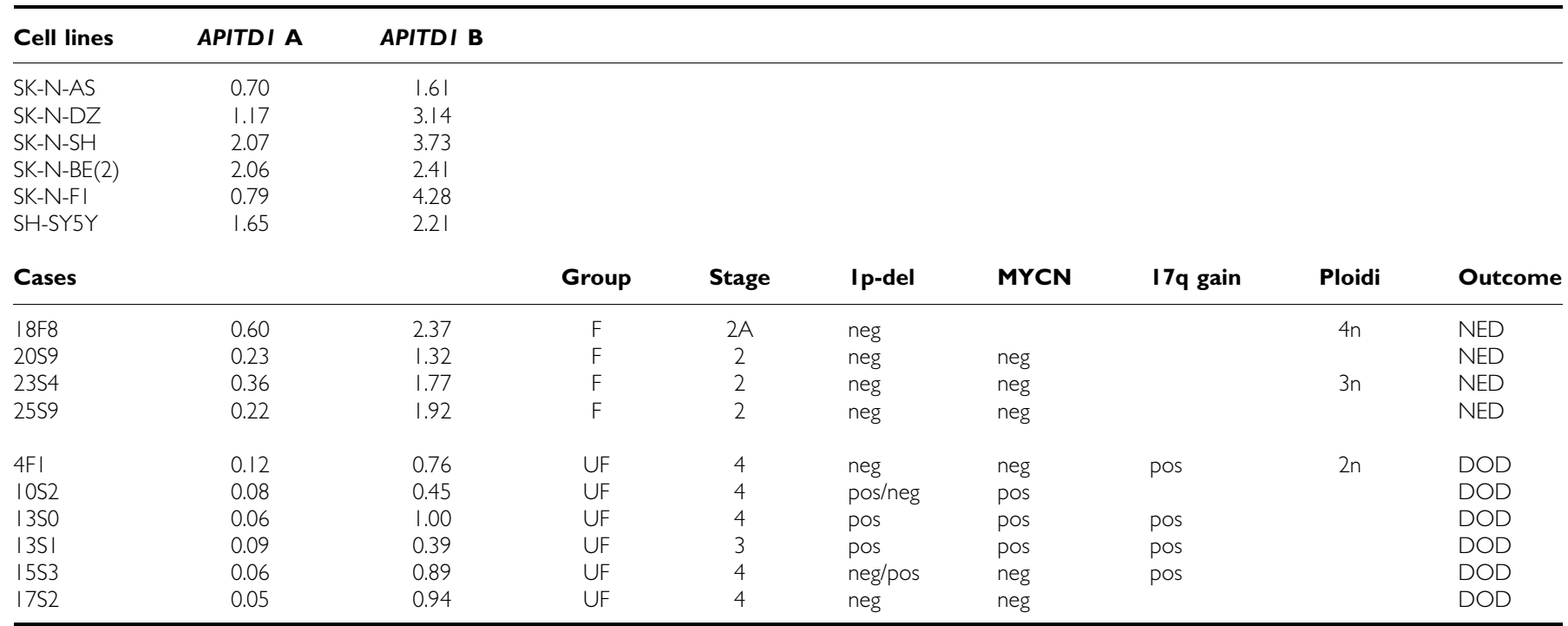

Column 2: relative amount of APITD I A expression. Column 3: relative amount of APITD / B expression. Column 4: F, favourable; UF, unfavourable; based on prognostic markers and the outcome of the disease. Columns 6-8: Ip-del, I p-deletion; MYCN, MYCN amplification; 17q gain, neg, negative; pos, positive; neg/pos; ambiguous results based on microsatellite marker analysis (according to Martinsson et al, 1995) and FISH, empty cells, not determined. Column I0: NED, no evidence of disease DOD, dead of disease.

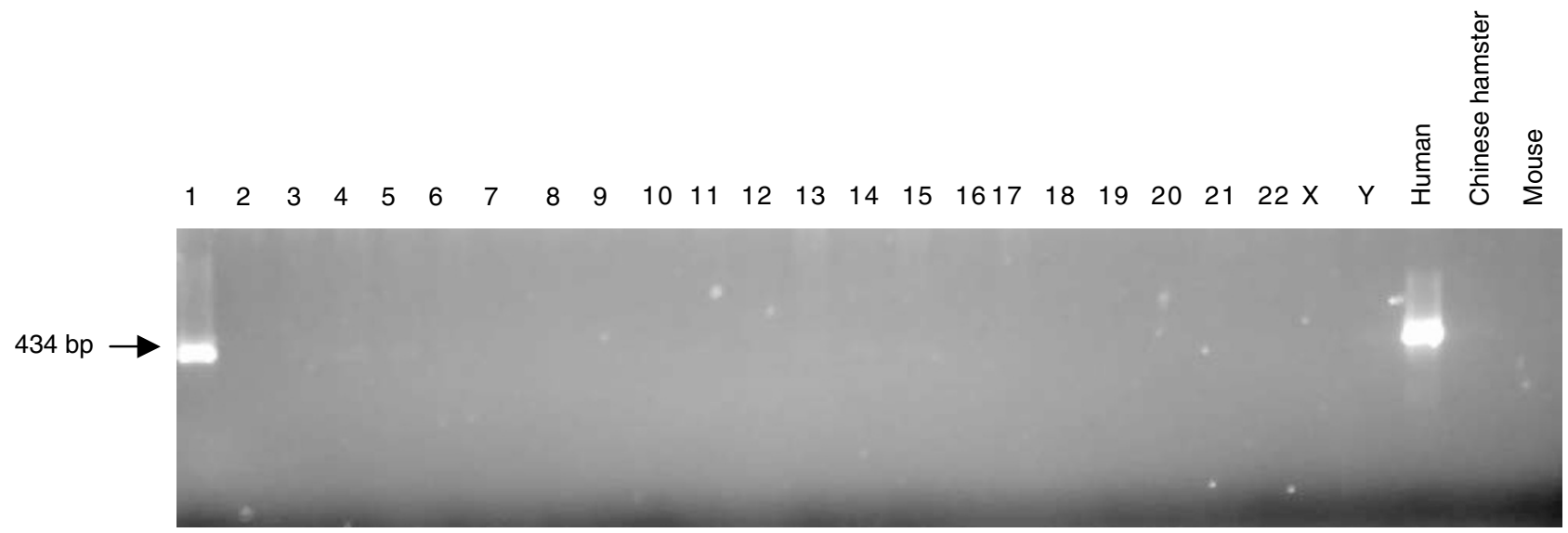

Figure 6 PCR amplification of APITD / exon 4 in a human/rodent somatic cell hybrid mapping panel. Amplification products of the appropriate size are obtained in the chromosome I cell hybrid and in the human cell line control exclusively.

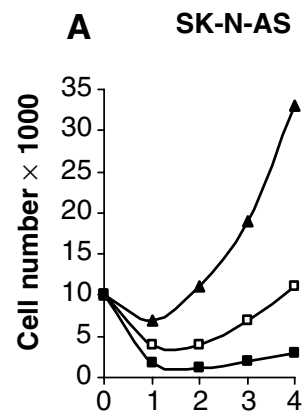

Days after transfection

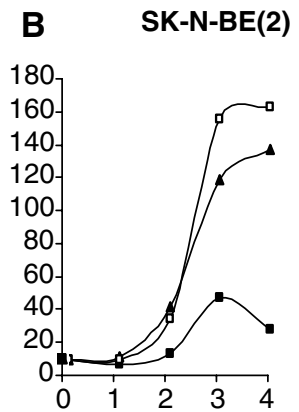

Days after transfection

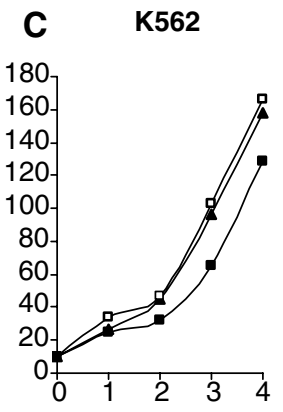

Days after transfection

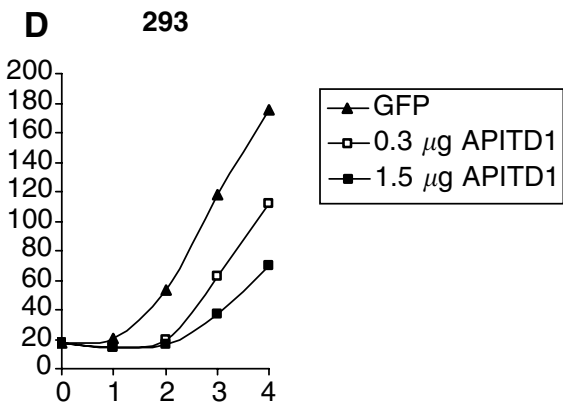

Days after transfection

Figure 7 Comparative growth curves of cell lines after transfection of I.5 $\mu \mathrm{g}$ GFP mRNA; $0.3 \mu \mathrm{g}$ APITD I A mRNA + I.2 $\mu \mathrm{g}$ GFP mRNA or I.5 $\mu \mathrm{g}$ APITD I A mRNA, respectively. (A) SK-N-AS (neuroblastoma). (B) SK-N-BE(2) (neuroblastoma). (C) K562 (lymphoblast). (D) 293 (transformed embryonal kidney).

days (Figure 7A). After 2-3 days, the number of SK-N-BE(2) cells in the $1.5 \mu \mathrm{g}$ APITD1A-transfected experiment was $60-70 \%$ below the GFP control and after 4 days the reduction was $80 \%$. The SK-N-
$\mathrm{BE}(2)$ cells transfected with a mix of $0.3 \mu \mathrm{g}$ APITD1A mRNA and $1.2 \mu \mathrm{g}$ GFP mRNA showed an increase in cell numbers by $20-30 \%$ compared to the GFP-transfected cells after 3-4 days (Figure 7B). 

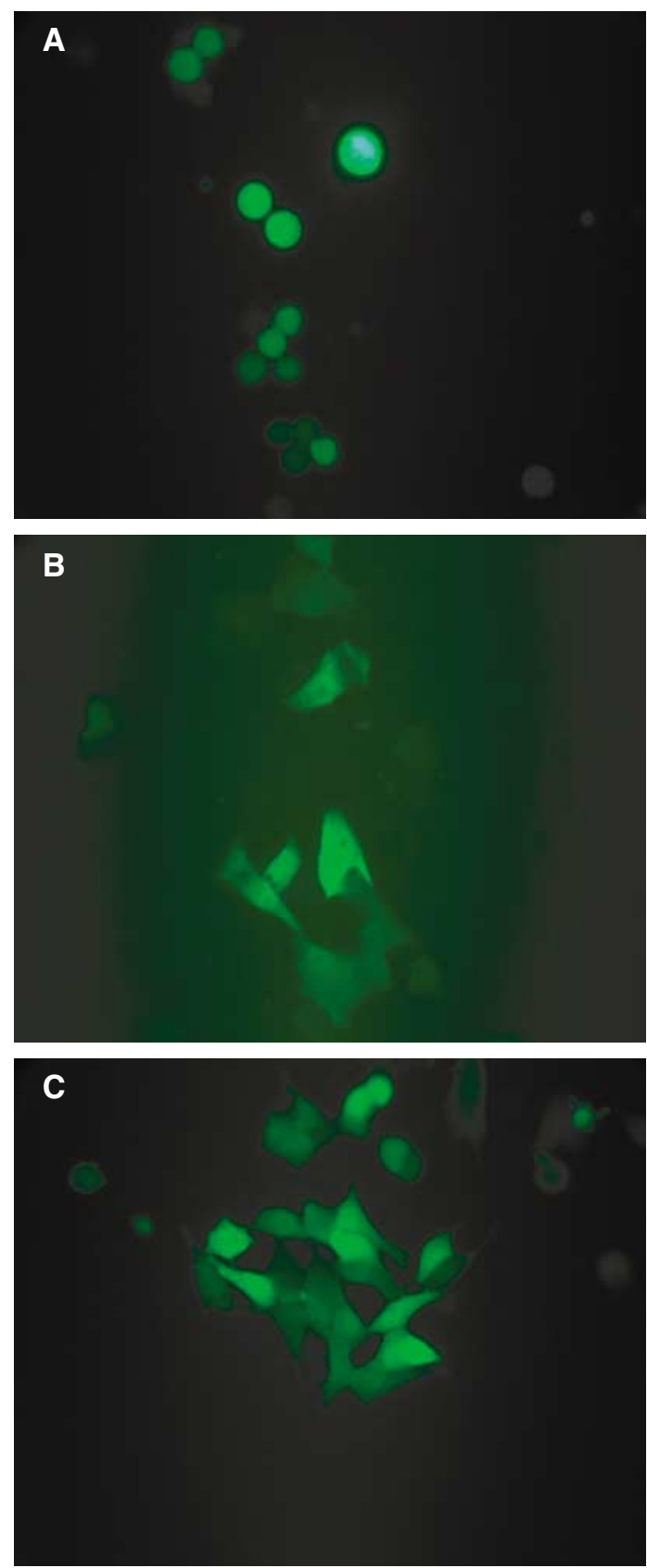

Figure 8 Expression of GFP in transfected cells shows that the mRNA has been introduced into the cells. (A) K562 (lymphoblast). (B) SK-N-AS (neuroblastoma). (C) SK-N-BE (neuroblastoma).

In K562 cells transfected with $1.5 \mu \mathrm{g}$ APITD1A mRNA, a slighter reduction in cell numbers of $20-30 \%$ could be seen after $2-4$ days. Also, in this experiment, there was a slight increase in the number of cells transfected with the lower concentration of APITD1A mRNA compared to the GFP-transfected control cells (Figure 7C). In 293 cells, an equal reduction in cell numbers could be seen after 2 days (60-70\%), for both APITD1A mRNA experiments compared to control cells. After 3-4 days of incubation, the experiment using $1.5 \mu \mathrm{g}$ APITD1A mRNA still showed $60-70 \%$ reduction, while the $0.3 \mu \mathrm{g}$ APITD1A mRNA experiment showed $40 \%$ reduction compared to control cells (Figure 7D). The transfection efficiency of GFP mRNA for SK-N-AS, SK-N-BE(2) and 293 cells was determined to $90 \%$ and for K562 to $60 \%$ fluorescence microscopy $24 \mathrm{~h}$ after transfection (Figure 8).

\section{Mutation analysis of APITD1}

No changes were found in the coding sequence of APITD1 in the tumour samples when compared to the reference samples. Variations that were identified in noncoding sequence are listed in Table 2.

\section{DISCUSSION}

Mutations in the tumour suppressor gene TP53, which has implications for tumorigenesis in many other tumour types (Nigro et al, 1989; Levine et al, 1991), are rare in primary neuroblastoma tumours (Imamura et al, 1993; Komuro et al, 1993; Vogan et al, 1993; Hosoi et al, 1994). A frequent characteristic of mainly advanced neuroblastoma tumours is deletion of the distal part of chromosome region $1 \mathrm{p}$, indicating that this is the location of a neuroblastoma tumour suppressor gene (NBS; OMIM 256700). Our group and others have tried to narrow down the consensus region of the NBS locus (Caron et al, 1995; Maris et al, 1995; Martinsson et al, 1995, 1997; White et al, 1995; Ichimiya et al, 1999; Bauer et al, 2001; Caron et al, 2001; Ejeskär et al, 2001; Maris et al, 2001; Spieker et al, 2001; White et al, 2001). In 2000, Ohira et al presented the first case of a homozygous deletion in the region in a neuroblastoma cell line. The $500 \mathrm{~kb}$ deletion partly overlaps the most proximal part of the consensus $\mathrm{LOH}$ region determined by us in our set of tumours. We have previously screened all annotated genes within this $500 \mathrm{~kb}$ region for mutations in neuroblastoma patients (Ejeskär et al, 2000; Abel et al, 2002; Krona et al, 2003). In this study, we have further explored this genomic region by the characterisation of a predicted gene, APITD1.

The coding sequence of the predicted gene in the neuroblastoma tumour suppressor candidate region on chromosome $1 \mathrm{p} 36.22$ is transcribed into alternative $5^{\prime}$ end mRNAs. The predicted aminoacid sequence of this gene, which we denoted APITD1 (ApoptosisInducing, TAF9-like Domain 1), is similar to the human TATA box-binding protein-associated factor $\mathrm{TAF}_{\mathrm{II}} 31$, a component of TFIID. $\mathrm{TAF}_{\mathrm{II}} 31$ has been identified as a critical protein required for p53-mediated transcriptional activation (Lu and Levine, 1995). The ATG start codon of the APITD1 A transcript occurs in a strong context, RNNatgG, where R is a purine (Kozak, 1996), suggesting that translation from this mRNA is active. However, despite the fact that the B transcript was shown to be ubiquitously expressed, the translational status of this mRNA must be considered with caution since there is no translation initiation site headed by a strong ATG codon (Kozak, 1996) in this transcript.

We have shown that expression of APITD1 transcript $\mathrm{A}$ is generally elevated in a set of eight foetal tissues compared with the same tissues from adults, with the most notable difference observed in cDNA extracted from brain and heart tissue, where the foetal expression was markedly elevated compared to the adult counterparts. Observed variations in band intensity should be reliably attributed to true differences in target mRNA abundance since the cDNA panel used has been previously normalised to the expression levels of at least four different housekeeping genes. Furthermore, replicate experiments resulted in comparable band intensities for each sample. The expression in neuroblastoma tumours of both transcripts was low when compared with neuroblastoma cell lines and normal tissues. Furthermore, a more sensitive quantification by real-time PCR revealed that the level of expression of both APITD1 transcripts was significantly reduced in a group of high-stage tumours from patients who had died from the disease when compared to a group of low-stage tumours from patients with no residual evidence of disease. The relatively strong expression of APITD1 transcript A in foetal tissues appears in strong contrast to the low expression in embryonal neuroblastoma tumours. We therefore propose that timed expression of APITD1 is important for the proper differentiation of foetal cells. On the other hand, expression of both APITD1 transcripts was also almost 
absent in a panel of other tumours than neuroblastoma, both adult (kidney) and paediatric (teratomas, Wilms' tumours, B-cell lymphomas and a pheochromocytoma). This indicates that APITD1 can have a more general significance for regulation of the cell cycle in normal cells.

We could show that APITD1A mRNA has a strong effect on cell growth in neuroblastoma cells (SK-N-BE(2) and SK-N-AS). The effect was dose dependent in SK-N-AS cells where the number of viable cells was decreased by $90 \% 2$ days after transfection in the APITD1A mRNA experiment compared to cells where an equal amount of GFP mRNA had been added. If four out of five of the APITD1A mRNA was exchanged to control mRNA, the decrease was $65 \% 2$ days after transfection (Figure 7A). There was also a clear reduction in the number of viable cells when SK-N-BE(2) was transfected with $1.5 \mu \mathrm{g}$ APITD1A mRNA. However, when $0.3 \mu \mathrm{g}$ of APITD1A mRNA was used, the SK-N-BE(2) cells were even growing faster after 3-4 days than the control cells did (Figure 7B). The effect of APITD1A mRNA on the cells could be due to a number of different reasons, that is, increased apoptosis, growth arrest, or some general toxicity of the APITD1A mRNA. The amount of mRNA added to each cell can always be argued, but still these experiments indicate that APITD1A indeed can have a role in an apoptotic or growth suppression pathway in neuroblastoma cells.

An effect could also be seen on 293 cells by adding APITD1A mRNA, even though not quite as strong $(60-70 \%$ reduction) as neuroblastoma cells (80-90\% reduction) after 4 days incubation. This difference in effect can of course depend on a number of reasons, like the amount of APITD1A mRNA per cell and the specific properties of the cells of these particular cell lines. However, one interesting thing to note is that the dose of APITD1A mRNA does not seem to make a difference the first couple of days after transfection in 293 cells. The difference in effect from the different doses comes first 3 days after transfection (Figure 7D). A difference this long after transfection might be due to the ability of the cell to break down mRNA. In the experiment with five times as much APITD1A mRNA, there will probably be more mRNA molecules left longer in the cell; thus the APITD1A mRNA will have time to affect more cells. The lymphoblast cell line K562 shows minor differences in cell growth between APITD1A mRNA experiments and control mRNA experiments (Figure 7C). Thus, APITD1A mRNA does not seem to activate any cell death or growth suppression pathway in these cells, as it seems to do in the neuroblastoma cell lines and in the transformed embryonic kidney cell line 293. However, these are indeed very different types of cells, and they are likely to be defective in different cellular pathways.

Thus, we have shown that APITD1A mRNA is capable of inducing cell death or growth suppression pathways in two neuroblastoma cell lines. As indicated in our expression studies, the level of APITD1 transcription in the neuroblastoma cell lines is intrinsically not as low as in the neuroblastoma tumours, which suggests that this is not the mechanism responsible for the immortality of neuroblastoma cell lines. Still, since the neuroblastoma cell lines are known to be different from primary tumours in many aspects (i.e. karyotype and milieu), it would not be surprising if they turned out to have different approaches than primary tumours to avoid the cell growth-regulating pathways of a normal cell.

Since APITD1 has a domain with homology to the human TATA box-binding protein-associated factor $\mathrm{TAF}_{\mathrm{II}} 31$, which has been identified as a critical protein required for p53-mediated transcriptional activation, expression of APITD1 might be necessary for the induction of apoptosis in defective foetal cells by the $\mathrm{p} 53$ pathway. There is also high sequence similarity between the translated ORF of APITD1A and translated expressed sequences from other organisms. For instance, 77 out of 83 $(92 \%)$ of the amino acids in a part of this hypothetical protein are identical to a translated nucleotide sequence from pig. By comparison, the alignment between the hypothetical TFIID-31 domain in APITD1 and the TFIID-31 domain in $\mathrm{TAF}_{\mathrm{II}} 31$ was only $57 \%$. Thus, it seems that APITD1 encodes an evolutionary conserved protein motive, similar to but different from $\operatorname{TAF}_{\mathrm{II}} 31$, in accordance with our hypothesis that APITD1 is a new member of the family of important proteins involved in cell regulation. In conclusion, we have characterised a novel gene, encoding a domain similar to a p53 transcription initiation factor, in the neuroblastoma tumour suppressor gene candidate region on chromosome 1p. We have demonstrated a preferred foetal expression of one transcript of the gene, which is in sharp contrast to its very weak or absent expression observed in neuroblastoma tumours. We have been able to show that APITD1 in fact has cell growth and/or cell death properties in neuroblastoma cells by functional studies of the APITD1A mRNA in cell lines. Future studies of APITD1 will be necessary to determine if it functions as a tumour suppressor gene upstream of TP53 and whether mutations in APITD1, although not commonly present in neuroblastoma, might be of importance in other tumour types.

\section{ACKNOWLEDGEMENTS}

We thank Frida Ponthan, Lena Klevenvall and Per Kogner for supplying us with cell lines and for scientific support. We are also grateful for help with TaqMan analyses from Elisabeth Odin, Erik Ulfhammer and the Swegene Gothenburg Genomics resource unit. This work was supported by grants from the Swedish Cancer Society, the Children's Cancer Foundation, the IngaBritt and Arne Lundberg Research Foundation, the King Gustav V Jubilee Clinic Cancer Research Foundation, the Assar Gabrielsson Foundation, the Wilhelm and Martina Lundgren Research Foundation, the Nilsson-Ehle Foundation and the Sahlgrenska University Foundation.

\section{REFERENCES}

Abel F, Sjöberg R-M, Ejeskär K, Krona C, Martinsson T (2002) Analyses of apoptotic regulators CASP9 and DFFA at 1 P36.2, reveal rare allele variants in human neuroblastoma tumours. Br J Cancer 86: 596-604

Bauer A, Savelyeva L, Claas A, Praml C, Berthold F, Schwab M (2001) Smallest region of overlapping deletion in $1 \mathrm{p} 36$ in human neuroblastoma: a 1 Mbp cosmid and PAC contig. Genes Chromosomes Cancer 31: $228-239$

Benn DE, Dwight T, Richardson AL, Delbridge L, Bambach CP, Stowasser M, Gordon RD, Marsh DJ, Robinson BG (2000) Sporadic and familial pheochromocytomas are associated with loss of at least two discrete intervals on chromosome 1p. Cancer Res 60: 7048-7051

Bridge JA, Liu J, Weibolt V, Baker KS, Perry D, Kruger R, Qualman S, Barr F, Sorensen P, Triche T, Suijkerbuijk R (2000) Novel genomic imbalances 
Hayes FA, Helson L, Kemshead J, Lampert F, Ninane J, Ohkawa H, Philip T, Pinkerton CR, Pritchard J, Sawada T, Siegel S, Smith EI, Tsuchida Y, Voute PA (1988) International criteria for diagnosis, staging, and response to treatment in patients with neuroblastoma. J Clin Oncol 6: $1874-1881$

Brodeur GM, Sekhon G, Goldstein MN (1977) Chromosomal aberrations in human neuroblastomas. Cancer 40: 2256-2263

Bussey KJ, Lawce HJ, Olson SB, Arthur DC, Kalousek DK, Krailo M, Giller R, Heifetz S, Womer R, Magenis RE (1999) Chromosome abnormalities of eighty-one pediatric germ cell tumors: sex-, age-, site-, and histopathology-related differences - a Children's Cancer Group study. Genes Chromosomes Cancer 25: 134-146

Caron H, Peter M, van Sluis P, Speleman F, de Kraker J, Laureys G, Michon J, Brugieres L, Voute PA, Westerveld A, Slater R, Delattre O, Versteeg R (1995) Evidence for two tumour suppressor loci on chromosomal bands 1p35-36 involved in neuroblastoma: one probably imprinted, another associated with N-myc amplification. Hum Mol Genet 4: 535-539

Caron H, Spieker N, Godfried M, Veenstra M, van Sluis P, de Kraker J, Voute P, Versteeg R (2001) Chromosome bands 1p35-36 contain two distinct neuroblastoma tumor suppressor loci, one of which is imprinted. Genes Chromosomes Cancer 30: 168-174

Ejeskär K, Abel F, Sjöberg R-M, Bäckström J, Kogner P, Martinsson T (2000) Fine mapping of the human preprocortistatin gene (CORT) to neuroblastoma consensus deletion region $1 \mathrm{p} 36.2-3$, but absence of mutations in primary tumors. Cytogenet Cell Genet 89: 62-66

Ejeskär K, Sjöberg R-M, Abel F, Kogner P, Ambros PF, Martinsson T (2001) Fine mapping of a tumour suppressor candidate gene region in $1 \mathrm{p} 36.2-$ 3 , commonly deleted in neuroblastomas and germ cell tumours. Med Pediatr Oncol 36: 61-66

Grundy PE, Telzerow PE, Breslow N, Moksness J, Huff V, Paterson MC (1994) Loss of heterozygosity for chromosomes $16 \mathrm{q}$ and $1 \mathrm{p}$ in Wilms tumors predicts an adverse outcome. Cancer Res 54: 2331-2333

Hosoi G, Hara J, Okamura T, Osugi Y, Ishihara S, Fukuzawa M, Okada A Okada S, Tawa A (1994) Low frequency of the p53 gene mutations in neuroblastoma. Cancer 73: 3087-3093

Ichimiya S, Nimura Y, Kageyama H, Takada N, Sunahara M, Shishikura T, Nakamura Y, Sakiyama S, Seki N, Ohira M, Kaneko Y, McKeon F, Caput D, Nakagawara A (1999) p73 at chromosome 1 p36.3 is lost in advanced stage neuroblastoma but its mutation is infrequent. Oncogene 18: $1061-1066$

Imamura J, Bartram CR, Berthold F, Harms D, Nakamura H, Koeffler HP (1993) Mutation of the p53 gene in neuroblastoma and its relationship with N-myc amplification. Cancer Res 53: 4053-4058

Komuro H, Hayashi Y, Kawamura M, Hayashi K, Kaneko Y, Kamoshita S, Hanada R, Yamamoto K, Hongo T, Yamada M, Tsuchida Y (1993) Mutations of the p53 gene are involved in Ewing's sarcomas but not in neuroblastomas. Cancer Res 53: 5284-5288

Kozak M (1996) Interpreting cDNA sequences: some insights from studies on translation. Mamm Genome 7: 563-574

Krona C, Ejeskär K, Abel F, Kogner P, Bjelke J, Björk E, Sjöberg R-M, Martinsson $T$ (2003) Screening for gene mutations in a $500 \mathrm{~kb}$ neuroblastoma tumor suppressor candidate region in chromosome $1 \mathrm{p}$; mutation and stage-specific expression in UBE4B/UFD2. Oncogene 22: $2343-2351$

Levine AJ, Momand J, Finlay CA (1991) The p53 tumour suppressor gene. Nature 351: 453-456

Li LC, Dahiya R (2002) MethPrimer: designing primers for methylation PCRs. Bioinformatics 18: $1427-1431$
$\mathrm{Lu} \mathrm{H}$, Levine AJ (1995) Human TAFII31 protein is a transcriptional coactivator of the p53 protein. Proc Natl Acad Sci USA 92: 5154-5158

Maris JM, Guo C, Blake D, White PS, Hogarty MD, Thompson PM, Rajalingam V, Gerbing R, Stram DO, Matthay KK, Seeger RC, Brodeur GM (2001) Comprehensive analysis of chromosome 1p deletions in neuroblastoma. Med Pediatr Oncol 36: 32-36

Maris JM, White PS, Beltinger CP, Sulman EP, Castleberry RP, Shuster JJ, Look AT, Brodeur GM (1995) Significance of chromosome 1p loss of heterozygosity in neuroblastoma. Cancer Res 55: 4664-4669

Martinsson T, Sjöberg R-M, Hallstensson K, Nordling M, Hedborg F, Kogner P (1997) Delimitation of a critical tumour suppressor region at distal 1p in neuroblastoma tumours. Eur J Cancer 33: 1997-2001

Martinsson T, Sjöberg R-M, Hedborg F, Kogner P (1995) Deletion of chromosome 1p loci and microsatellite instability in neuroblastomas analyzed with short-tandem repeat polymorphisms. Cancer Res 55: $5681-5686$

Mostert M, Rosenberg C, Stoop H, Schuyer M, Timmer A, Oosterhuis W, Looijenga L (2000) Comparative genomic and in situ hybridization of germ cell tumors of the infantile testis. Lab Invest 80: 1055-1064

Nigro JM, Baker SJ, Preisinger AC, Jessup JM, Hostetter R, Cleary K, Bigner SH, Davidson N, Baylin S, Devilee P, Glover T, Collins FS, Weston A, Modali R, Harris CC, Vogelstein B (1989) Mutations in the p53 gene occur in diverse human tumour types. Nature 342: 705-708

Ohira M, Kageyama H, Mihara M, Furuta S, Machida T, Shishikura T, Takayasu H, Islam A, Nakamura Y, Takahashi M, Tomioka N, Sakiyama S, Kaneko Y, Toyoda A, Hattori M, Sakaki Y, Ohki M, Horii A, Soeda E, Inazawa J, Seki N, Kuma H, Nozawa I, Nakagawara A (2000) Identification and characterization of a $500-\mathrm{kb}$ homozygously deleted region at $1 \mathrm{p} 36.2-\mathrm{p} 36.3$ in a neuroblastoma cell line. Oncogene 19: $4302-4307$

Rodriguez E, Mathew S, Reuter V, Ilson DH, Bosl GJ, Chaganti RS (1992) Cytogenetic analysis of 124 prospectively ascertained male germ cell tumors. Cancer Res 52: 2285-2291

Schneider DT, Schuster AE, Fritsch MK, Calaminus G, Harms D, Gobel U, Perlman EJ (2001) Genetic analysis of childhood germ cell tumors with comparative genomic hybridization. Klin Peadiatr 213: 204-211

Spieker N, Beitsma M, Van Sluis P, Chan A, Caron H, Versteeg R (2001) Three chromosomal rearrangements in neuroblastoma cluster within a 300-kb region on 1p36.1. Genes Chromosomes Cancer 31: 172-181

Steinberg R, Freud E, Zer M, Ziperman I, Goshen Y, Ash S, Stein J, Zaizov R, Avigad S (2000) High frequency of loss of heterozygosity for 1p35-p36 (D1S247) in Wilms tumor. Cancer Genet Cytogenet 117: $136-139$

Stock C, Ambros IM, Strehl S, Zoubek A, Fink FM, Gadner H, Ambros PF (1995) Cytogenetic aspects of pediatric germ cell tumors. Klin Peadiatr 207: $235-241$

Vogan K, Bernstein M, Leclerc JM, Brisson L, Brossard J, Brodeur GM, Pelletier J, Gros P (1993) Absence of p53 gene mutations in primary neuroblastomas. Cancer Res 53: 5269-5273

White PS, Maris JM, Beltinger C, Sulman E, Marshall HN, Fujimori M, Kaufman BA, Biegel JA, Allen C, Hilliard C, Valentine MB, Look AT, Enomoto H, Sakiyama S, Brodeur GM (1995) A region of consistent deletion in neuroblastoma maps within human chromosome 1p36.2 36.3. Proc Natl Acad Sci USA 92: 5520-5524

White PS, Thompson PM, Seifried BA, Sulman EP, Jensen SJ, Guo C, Maris JM, Hogarty MD, Allen C, Biegel JA, Matise TC, Gregory SG, Reynolds CP, Brodeur GM (2001) Detailed molecular analysis of $1 \mathrm{p} 36$ in neuroblastoma. Med Pediatr Oncol 36: 37-41 